\title{
Partial purification and biochemical characterization of a new highly acidic NYSO laccase from Alcaligenes faecalis
}

\author{
Soad A. Abdelgalil', Ahmad R. Attia², Reyed M. Reyed ${ }^{1}$ and Nadia A. Soliman ${ }^{1 *}$
}

\begin{abstract}
Background: Due to the multitude industrial applications of ligninolytic enzymes, their demands are increasing. Partial purification and intensive characterization of contemporary highly acidic laccase enzyme produced by an Egyptian local isolate designated Alcaligenes faecalis NYSO were studied in the present investigation.

Results: Alcaligenes faecalis NYSO laccase has been partially purified and intensively biochemically characterized. It was noticed that 40-60\% ammonium sulfate saturation showed maximum activity. A protein band with an apparent molecular mass of $\sim 50 \mathrm{kDa}$ related to NYSO laccase was identified through SDS-PAGE and zymography. The partially purified enzyme exhibited maximum activity at $55^{\circ} \mathrm{C}$ and pH suboptimal (2.5-5.0). Remarkable activation for enzyme activity was recognized after 10 -min exposure to temperatures (T) 50, 60, and $70^{\circ} \mathrm{C}$; time elongation caused inactivation, where $\sim 50 \%$ of activity was lost after a $7-h$ exposure to $60{ }^{\circ} \mathrm{C}$. Some metal ions $\mathrm{Cu}^{2+}, \mathrm{Zn}^{2+}, \mathrm{Co}^{2+} \mathrm{Ni}^{2+}, \mathrm{Mn}^{2+}, \mathrm{Cd}^{2+}, \mathrm{Cr}^{2+}$, and $\mathrm{Mg}^{2+}$ caused strong stimulation for enzyme activity, but $\mathrm{Fe}^{2+}$ and $\mathrm{Hg}^{2+}$ reduced the activity. One millimolar of chelating agents [ethylenediamine tetraacetic acid (EDTA), sodium citrate, and sodium oxalate] caused strong activation for enzyme activity. Sodium dodecyl sulfate (SDS), cysteine-HCl, dithiothreitol (DTT), $\beta$-mercaptoethanol, thioglycolic acid, and sodium azide caused strong inhibition for NYSO laccase activity even at low concentration. One millimolar of urea, imidazole, kojic acid, phenylmethylsulfonyl fluoride (PMSF), $\mathrm{H}_{2} \mathrm{O}_{2}$, and Triton X-100 caused activation. The partially purified NYSO laccase had decolorization activity towards different dyes such as congo red, crystal violet, methylene blue, fast green, basic fuchsin, bromophenol blue, malachite green, bromocresol purple eriochrome black T, and Coomassie Brilliant Blue R-250 with various degree of degradation. Also, it had a vast range of substrate specificity including lignin, but with high affinity towards p-anisidine.

Conclusion: The promising properties of the newly studied laccase enzyme from Alcaligenes faecalis NYSO strain would support several industries such as textile, food, and paper and open the possibility for commercial use in water treatment. It will also open the door to new applications due to its ligninolytic properties in the near future.
\end{abstract}

Keywords: Laccase, Purification, Alcaligenes faecalis NYSO, Decolorization

\footnotetext{
* Correspondence: nadiastuttgart@yahoo.com

${ }^{1}$ Bioprocess Development Department, Genetic Engineering and

Biotechnology Research Institure (GEBRI), City of Scientific Research and

Technological Applications (SRTA-City), New Burg El-Arab City, Alexandria

21934, Egypt

Full list of author information is available at the end of the article
}

\section{Springer Open}

(c) The Author(s). 2020 Open Access This article is licensed under a Creative Commons Attribution 4.0 International License, which permits use, sharing, adaptation, distribution and reproduction in any medium or format, as long as you give appropriate credit to the original author(s) and the source, provide a link to the Creative Commons licence, and indicate if changes were made. The images or other third party material in this article are included in the article's Creative Commons licence, unless indicated otherwise in a credit line to the material. If material is not included in the article's Creative Commons licence and your intended use is not permitted by statutory regulation or exceeds the permitted use, you will need to obtain permission directly from the copyright holder. To view a copy of this licence, visit http://creativecommons.org/licenses/by/4.0/. 


\section{Background}

In the past few years, enzymatic bioremediation has become an attractive alternative to further support the bio-treatment techniques, where the most currently available enzymes provide simpler systems than a whole organism [1]. Most xenobiotics can be submitted to enzymatic bioremediation, for example, polycyclic aromatic hydrocarbons (PAHs), polynitrated aromatic compounds, pesticides such as organochlorine insecticides, bleach-plant effluents, synthetic dyes, polymers, and wood preservatives (creosote, pentachlorophenol) [2]. Historically, the most studied enzymes in bioremediation are bacterial mono- or di-oxygenases, reductases, dehalogenases, cytochrome P450 monooxygenases, enzymes involved in lignin metabolism (such as laccases and lignin and manganese peroxidases), and bacterial phosphotriesterases [3]. From an environmental point of view, the use of enzymes instead of chemicals or microorganisms undoubtedly presents some advantages $[4,5]$. Laccases (EC 1.10.3.2, benzenediol-oxygen oxidoreductase) are either mono- or multimeric copper-containing oxidases that catalyze the reduction of oxygen to water accompanied by the oxidation of phenolic and non-phenolic substrates. Laccases catalyzed the oxidation of a wide variety of organic and inorganic substrates, including mono-, di-, and polyphenols, amino phenols, methoxy phenols, aromatic amines, and ascorbate with the concomitant four-electron reduction of oxygen to water [6]. Intensive studies focused on laccases [7] because of their ability to oxidize phenolic/non-phenolic compounds as well as reduce molecular oxygen. Laccases have been found in various plants, bacteria, and also fungi; they play important roles in many cellular or microbial activities $[8,9]$.

Many of the industrial applications of the ligninolytic enzymes (viz, dye decolorization, phenol degradation, biobleaching, etc.) require only crude preparations of the enzyme, and in such cases, the enzyme purification is not obligatory. However, in certain cases, purified enzymes are also used for some applications [10]. The purification and enrichment of lignin-degrading enzymes such as laccases are of great interest. Moreover, ammonium sulfate fractionation is commonly used to partially purify laccases from the crude sources [11].

Due to the high industrial applicability of laccases, this study addressed the partial purification, stability characteristics of a laccase produced by Alcaligenes faecalis NYSO, and its decolorization activity towards different dyes.

\section{Methods}

\section{Microorganism maintenance}

A. faecalis is a Gram-negative, alkali-tolerant, rod-shaped bacterium with flagella, commonly found in soil water, and other environments, and belong to the Alcaligenaceae family. In this study, A. faecalis strain NYSO (KP859538) isolated from a discharged effluent of tanning and leather industry, Alexandria, Egypt, was used and identified by 16S rRNA as described previously by Abdel Galil et al. [12]. Due to its feature as alkali-tolerant, it was grown and maintained in buffered LB agar slants (glycine- $\mathrm{NaOH}, \mathrm{pH}$ 8.9) [12].

\section{Laccase activity assay and protein estimation}

The bacterial cells were grown in a previously optimized buffered medium [12], and the cells were harvested by centrifugation $\left(6000 \mathrm{rpm}, 4{ }^{\circ} \mathrm{C}, 30 \mathrm{~min}\right)$, washed with citratephosphate buffer $(0.1 \mathrm{M}, \mathrm{pH} 5.0)$, suspended in $5 \mathrm{ml}$ of the same buffer, chilled in ice, then sonicated $(5 \times 45 \mathrm{~s})$ at high-frequency ultrasound (HFU $20 \mathrm{MHz}$ ) [13]. Subsequently, the cell lysate was used for the quantitative determination of laccase activity and protein concentration after separating the cell debris by centrifugation $(10,000 \mathrm{rpm}$, $\left.4{ }^{\circ} \mathrm{C}, 30 \mathrm{~min}\right)$. Laccase activity has been estimated by a colorimetric method using 2,2' -Azino-bis(3-ethylbenzothiazoline-6-sulfonic acid) (ABTS, Sigma Aldrich) as described by Niku-Paavola et al. [14]. The reaction mixture, composed of $25 \mu \mathrm{l}$ of appropriately diluted enzyme extract, $1125 \mu \mathrm{l}$ of $0.1 \mathrm{M}$ citrate-phosphate buffer $\mathrm{pH} 4.0$, and $350 \mu \mathrm{l}$ of $20 \mathrm{mM}$ of ABTS substrate, was incubated after mixing at $55^{\circ} \mathrm{C}$ for $10 \mathrm{~min}$. One unit of enzyme activity is defined as the amount of enzyme that catalyzes the oxidization $1.0 \mu \mathrm{mol}$ of ABTS per minute under the above assay conditions; the activity was expressed in $\mathrm{U} / \mathrm{L}$ according to the following equation: activity $(\mathrm{U} / \mathrm{L})=\Delta \mathrm{Abs} . / \Delta t \times V_{t} /\left(\varepsilon \times d \times V_{\mathrm{s}}\right)$, where $V_{t}$ is the total volume of the assay, 29,300 is the millimolar extinction coefficient $(\varepsilon)$ of ABTS, $d$ is cuvette width $(\mathrm{cm})$, and $V_{\mathrm{s}}$ is the enzyme volume used in the assay.

Protein concentration was determined by Lowry et al. [15]. Bovine serum albumin (BSA, Sigma) was used for the standard curve. All enzyme assay or protein concentration measurements were expressed as the average of three reading and calculated standard deviation included according to Altman and Martin-Brand [16].

\section{Enzyme partial purification}

Forty microliters of the crude intracellular enzyme was subjected to fractional precipitation by ammonium sulfate. Salt saturation was standardized by using different cuts (0-40, 40-60, and 60-80\%) of ammonium sulfate. The protein precipitate of each fraction was collected by centrifugation $\left(12,000 \mathrm{rpm}, 30 \mathrm{~min}, 4{ }^{\circ} \mathrm{C}\right)$, then suspended in $10 \mathrm{ml}$ of 0.1 $\mathrm{M}$ citrate-phosphate buffer, $\mathrm{pH} 5.0$, and dialyzed at $4{ }^{\circ} \mathrm{C}$ against the same buffer using the dialysis bag with an exclusion limit of $12 \mathrm{kDa}$.

\section{SDS-polyacrylamide gel electrophoresis and zymography}

SDS-PAGE was performed on $12 \%$ running non-native gels as described by Laemmli [17], and resolved proteins were visualized by Coomassie Brilliant Blue R-250 staining following standard procedures. A pre-stained protein 
marker of broad range (6-175 kDa, Bio Labs, New England) was used as a molecular mass marker. Laccase activity within the gel was detected as described by Sheikhi et al. [13]. After running, the gel was incubated with 2.5\% Triton X-100 (Applichem) in $0.1 \mathrm{M}$ citratephosphate buffer ( $\mathrm{pH} 4.0$ ) under conditions (room $\mathrm{T}$, shaking, $30 \mathrm{~min}$ ). Afterward, it was washed five times with $0.1 \mathrm{M}$ citrate-phosphate buffer $\mathrm{pH} 4.0$ and incubated with $20 \mathrm{mM} \mathrm{ABTS}$ at $55{ }^{\circ} \mathrm{C}$ till the appearance of the active band (green colored).

\section{Enzyme characterization}

\section{Temperature and $\mathrm{pH}$ optimum}

To determine the optimum $\mathrm{T}$ for the partially purified NYSO laccase enzyme, the reaction was carried out at different $\mathrm{T}$, ranging from 25 to $70{ }^{\circ} \mathrm{C}$. On the other hand, to detect the optimum $\mathrm{pH}$, the activity of the tested enzyme was measured at different $\mathrm{pH}$ values (2.5-10.0). $0.1 \mathrm{M}$ of the following buffers: citrate-phosphate buffer, phosphate buffer, and glycine-sodium hydroxide buffer was used for the following specified $\mathrm{pH}$ values: $2.5-6.0,7-8$, and 9-10, respectively. The assay reaction was carried out at optimum $\mathrm{T}$.

\section{Temperature and $\mathrm{pH}$ stability}

Thermal stability of the partially purified NYSO laccase was determined by measuring the residual enzyme activity at time intervals $1,2,3,4,5,6,7,8$, and $50 \mathrm{~h}$, after incubating an aliquot of the enzyme at $\mathrm{T}\left(30-80{ }^{\circ} \mathrm{C}\right.$, interval 10), compared to the untreated enzyme. $\mathrm{pH}$ stability of the tested laccase was determined by measuring the residual enzyme activity at time intervals $1,3,5$, and $25 \mathrm{~h}$, after incubating an aliquot of the enzyme at $\mathrm{pH} 2.5$, 3.0, 4.0, 5.0, and 6.0, each with the correct buffer as mentioned before. NYSO laccase activity of each sample was measured under optimal assay conditions $\left(\mathrm{T} 55^{\circ} \mathrm{C}\right.$ and $\mathrm{pH} 4.0$ ) and compared to the control.

\section{Thermal inactivation and storage stability}

Aliquots of the partially purified enzyme solution were incubated for $10 \mathrm{~min}$ at $30,40,50,60,70,80,90$, and $95^{\circ} \mathrm{C}$, then the residual activity of the laccase was estimated compared to the untreated enzyme, while, for detection of the storage stability of the partially purified enzyme, aliquots of the enzyme solution were stored at $4.0{ }^{\circ} \mathrm{C}$, room $\mathrm{T}\left(25{ }^{\circ} \mathrm{C}\right)$, and $-20^{\circ} \mathrm{C}$ for 46 days. The residual activity of the laccase was estimated at different time intervals for each T. NYSO laccase activity of each sample was measured under optimal assay conditions ( $\mathrm{T}$ $55^{\circ} \mathrm{C}$ and $\left.\mathrm{pH} 4.0\right)$ and compared to the control.

\section{Effects of some metal ions and some chemical agents on enzyme activity}

The effect of different metal ions $\left(\mathrm{Mg}^{2+}, \mathrm{Cr}^{2+}, \mathrm{Mn}^{2+}\right.$, $\mathrm{Hg}^{2+}, \mathrm{Cu}^{2+}, \mathrm{Fe}^{2+}, \mathrm{Ni}^{2+}, \mathrm{Cd}^{2+}, \mathrm{Zn}^{2+}$, and $\mathrm{Co}^{2+}$ ) on the activity of the partially purified NYSO laccase was measured under optimal conditions ( $\mathrm{T} 55^{\circ} \mathrm{C}$ and $\mathrm{pH} 4.0$ ), after 10-min exposure of enzyme to different metal concentrations $(1$ and $10 \mathrm{mM})$. Also, the effect of some chemicals like chelators (EDTA, sodium citrate, and sodium oxalate), inhibitors (sodium azide, DTT, urea, imidazole, kojic acid, cysteine- $\mathrm{HCl}, \beta$-mercaptoethanol, thioglycolic acid, PMSF, $\mathrm{H}_{2} \mathrm{O}_{2}$ ), and surfactants (Triton X-100, SDS) on NYSO laccase activity was carried out by pre-incubating the enzyme with the tested agent at concentrations $(1$ and $10 \mathrm{mM})$ for $10 \mathrm{~min}$ at room temperature. The residual activity was assayed at optimal conditions and compared to the untreated enzyme.

\section{Enzyme decolorization potential}

The decolorizing ability of the partially purified laccase was evaluated by using different synthetic dyes $(0.2 \mathrm{~g} \%)$ such as malachite green $\left(\lambda_{\max }=616\right)$, fast green $\left(\lambda_{\max }=\right.$ 625), crystal violet $\left(\lambda_{\max }=590\right)$, congo red $\left(\lambda_{\max }=497\right)$, eriochrome black T $\left(\lambda_{\max }=503\right)$, bromophenol blue $\left(\lambda_{\max }\right.$ =592), methylene blue $\left(\lambda_{\max }=665\right)$, Coomassie Brilliant Blue R-250 $\left(\lambda_{\max }=465\right)$, bromocresol purple $\left(\lambda_{\max }=419\right)$, and basic fuchsin $\left(\lambda_{\max }=544\right)$. Dyes were incubated with (50 $\mu \mathrm{l}=\sim 84.5$ Units) aliquots of the partially purified laccase solution in $0.1 \mathrm{M}$ citrate-phosphate buffer $(\mathrm{pH} 4.0)$ containing $10 \mathrm{mM} \mathrm{CuSO} 4.5 \mathrm{H}_{2} \mathrm{O}$ at $55^{\circ} \mathrm{C}$ for $1 \mathrm{~h}$. Control samples without the enzyme were processed in parallel with the tested samples. The decolorization ability of laccase was determined spectrophotometrically as the relative decrease of absorbance at each maximal absorbance wavelength of the dyes. The decolorization efficiency of laccase for each dye is shown as dye decolorization (\%). The decolorization efficiency $D \%$ was calculated as follows: dye decolorization percentage $=[($ initial absorbance - final absorbance) $/($ initial absorbance $)] \times 100$

Average decolorization rate $=C \times D \% \times 1000 / 100 \times t$, where $C=$ initial concentration of dye $(\mathrm{mg} / \mathrm{L})$ and $D \%=$ dye decolorization (\%) after time $(t)$ [18].

\section{Substrate specificity}

Spectrophotometric measurements of substrate oxidation by the partially purified enzyme were investigated at the optimal conditions $\left(\mathrm{pH} 4\right.$ and $\left.\mathrm{T} 55^{\circ} \mathrm{C}\right)$ and different concentrations $(1.0$ and $20 \mathrm{mM})$ using $1.5 \mathrm{ml}$ reaction mixtures containing tested substrate viz., ABTS $\left(\varepsilon=29.3 \mathrm{mM}^{-1} \mathrm{~cm}^{-1}\right.$, $\left.\lambda_{\max }=436 \mathrm{~nm}\right)$, catechol $\left(\varepsilon=26 \mathrm{mM}^{-1} \mathrm{~cm}^{-1}, \lambda_{\max }=450\right.$ $\mathrm{nm})$, pyrogallol $\left(\varepsilon=35 \mathrm{mM}^{-1} \mathrm{~cm}^{-1}, \lambda_{\max }=450 \mathrm{~nm}\right)$, panisidine $\left(\varepsilon=1.173 \mathrm{mM}^{-1} \mathrm{~cm}^{-1}, \quad \lambda_{\max }=350 \mathrm{~nm}\right)$, 4nitrophenol $\left(\varepsilon=18.1 \mathrm{mM}^{-1} \mathrm{~cm}^{-1}, \lambda_{\max }=405 \mathrm{~nm}\right)$, hydroquinone $\left(\varepsilon=17.542 \mathrm{mM}^{-1} \mathrm{~cm}^{-1}, \lambda_{\max }=525 \mathrm{~nm}\right)$, 4aminophenol $\left(\varepsilon=3.4 \mathrm{mM}^{-1} \mathrm{~cm}^{-1}, \lambda_{\max }=470 \mathrm{~nm}\right)$, pphenylenediamine $\left(\varepsilon=14.68 \mathrm{mM}^{-1} \mathrm{~cm}^{-1}, \lambda_{\max }=525 \mathrm{~nm}\right)$, syringaldazine $\left(\varepsilon=65 \mathrm{mM}^{-1} \mathrm{~cm}^{-1}, \lambda_{\max }=530 \mathrm{~nm}\right)$, guaiacol $\left(\varepsilon=26.6 \mathrm{mM}^{-1} \mathrm{~cm}^{-1}, \lambda_{\max }=465 \mathrm{~nm}\right)$, tannic acid $(\varepsilon=$ 
$\left.27.200 \mathrm{mM}^{-1} \mathrm{~cm}^{-1}, \lambda_{\max }=458 \mathrm{~nm}\right)$, and vanillic acid $(\varepsilon=$ $\left.2.340 \mathrm{mM}^{-1} \mathrm{~cm}^{-1}, \lambda_{\max }=390 \mathrm{~nm}\right)$.

\section{Results}

Partial purification of NYSO laccase

Partial purification of the crude laccase from cell lysate of $A$. faecalis strain NYSO was carried out in three sequential steps through ammonium sulfate precipitation; the saturation $40-60 \%$ showed the maximum laccase activity (Table 1). Protein homogeneity of the partially purified NYSO laccase was checked through SDS-PAGE (Fig. 1). It was obviously recognized that there was a gradual decline of protein bands from crude extract passing to three fractionation stages. NYSO laccase activity in gel (activity staining) using ABTS substrate resulted in the appearance of an active green band at approximate molecular mass $\sim 50 \mathrm{kDa}$.

\section{Physicochemical characterization of the partially purified laccase \\ Effect of reaction $\mathrm{T}$ and $\mathrm{pH}$ on the enzyme activity}

The influence of reaction $\mathrm{T}$ on the enzyme activity was addressed at various incubation $\mathrm{T}\left(25-70{ }^{\circ} \mathrm{C}\right)$. The highest activity was obtained at $55^{\circ} \mathrm{C}$, while at $25{ }^{\circ} \mathrm{C}$ and 70 ${ }^{\circ} \mathrm{C}$, the activity decreased to about $56 \%$ and $69 \%$, respectively, when compared to the optimum T (Fig. 2).

On $\mathrm{pH}$ profile, the partially purified enzyme works in a wide range of $\mathrm{pH}(2.5-6.0)$, but it had a preference to work at low $\mathrm{pH}$ and the optimal at 4.0 (Fig. 3). Additionally, there was a decline in activity $(20 \%, 56.1 \%$, and $82.8 \%)$ at $\mathrm{pH} 3,5$, and 6, respectively, when compared to $\mathrm{pH}$ 4.0. However, almost all activity (96.4\%) was lost at neutral and no activity was detected at $\mathrm{pH} 8.0,9.0$, and 10.0.

\section{Thermal and $\mathrm{pH}$ stability of laccase enzyme}

The partial purified intracellular NYSO laccase exhibited high thermal stability as shown in Fig. 4. The enzyme retained about $86.3 \%, 35 \%$, and $7 \%$ of its activity after 8 h exposure to $40{ }^{\circ} \mathrm{C}, 60{ }^{\circ} \mathrm{C}$, and $70{ }^{\circ} \mathrm{C}$, respectively, when compared to the initial activity, while no loss in activity $(100 \%)$ was recorded at $50{ }^{\circ} \mathrm{C}$ up to 8 -h exposure.

By studying the $\mathrm{pH}$ stability of the enzyme, it found that the enzyme was highly stable at $\mathrm{pH} 4$ and 5 through 24-h incubation, retaining more than $92.4 \%$ and $100.3 \%$,

Table 1 NYSO laccase protein fractionation using different saturation percentage of ammonium sulfate

\begin{tabular}{lll}
\hline Purification stages & Total activity $^{\mathbf{a}}(\mathbf{U})$ & Total protein $^{\mathbf{a}} \mathbf{( m g )}$ \\
\hline Crude enzyme & 1288.7 & 22.005 \\
0-40 (pellets) & 204.8 & 18.694 \\
$40-60$ (pellets) & 1690.1 & 11.951 \\
$60-80$ (pellets) & 576.1 & 1.534 \\
\hline
\end{tabular}

${ }^{\mathrm{a}}$ Activity $(\mathrm{U})$ and protein $(\mathrm{mg})$ are mean of three reading respectively, of the original activity. In contrast, the enzyme was unstable at $\mathrm{pH} 6.0$, where about $49.1 \%$ of activity remained after 5-h incubation as shown in Fig. 5.

\section{Thermal inactivation of laccase}

Figure 6 shows a gradual stimulation of the enzyme activity, when the enzyme was pre-incubated for $10 \mathrm{~min}$ at T 30, 40, 50, 60, and $70{ }^{\circ} \mathrm{C}$. After that, a sharp drop in activity was observed. The enzyme showed high stability after 10 -min pre-incubation at tested $\mathrm{T}$ up to $70{ }^{\circ} \mathrm{C}$; however, it was noticed that there were $45 \%$ and $66 \%$ decrease upon pre-incubation at 80 and $90{ }^{\circ} \mathrm{C}$, respectively.

On the other hand, storage stability results of the studied enzyme explained that it was more stable at -20 and $4{ }^{\circ} \mathrm{C}$ than room $\mathrm{T}$ along storage time (46 days) as shown in Fig. 7. It maintained $82 \%$ and $\sim 50 \%$ of its activity after 5 -day incubation at $4{ }^{\circ} \mathrm{C}$ and room $\mathrm{T}\left(25^{\circ} \mathrm{C}\right)$, respectively. This means a short shelf-life for the tested partially purified laccase at room $\mathrm{T}$. Consequently, after 46 days (at room $\mathrm{T}$ ), the enzyme retained only $16.9 \%$ of its activity.

\section{Effect of some metal ions and chemical reagents on laccase activity}

The effect of various divalent metal ions at concentrations of 1 and $10 \mathrm{mM}$ on the enzyme activity was assessed and presented in Table 2. The results showed that NYSO laccase activity was enhanced in the presence of $\mathrm{Cu}^{2+}, \mathrm{Ni}^{2+}$, $\mathrm{Co}^{2+}, \mathrm{Cd}^{2+}$, and $\mathrm{Mn}^{2+}$ metal ions at concentration $10 \mathrm{mM}$, in ascending order. Moreover, $\mathrm{Zn}^{2+}, \mathrm{Cr}^{2+}$, and $\mathrm{Mg}^{2+}$ metal ions at concentration $1 \mathrm{mM}$ caused stimulation of activity, while lesser stimulation occurred at $10 \mathrm{mM}$ (Table 2). On the other hand, both $\mathrm{Fe}^{2+}$ and $\mathrm{Hg}^{2+}$ metal ions (1 and 10 $\mathrm{mM}$ ) caused strong inhibition for NYSO laccase activity as shown in Table 2. Also, the effects of several chelating agents and potential inhibitors on the partially purified NYSO laccase activity were investigated and reported in Table 2. Generally, the used chelating agents caused an enhancement in activity; EDTA stimulated the tested enzyme two times at $1 \mathrm{mM}$ concentration, while it was strongly inhibited at $10 \mathrm{mM}$ compared to the untreated enzyme sample. Sodium citrate and oxalate caused limited activation (14.7 and 3.6\%) and slight inhibition (0.6 and $4.1 \%)$ at $1.0 \mathrm{mM}$ and $10 \mathrm{mM}$, respectively. SDS, $\beta$ mercaptoethanol, DTT, cysteine- $\mathrm{HCl}$, thioglycolic acid, and sodium azide showed an excited trend of decreasing the activity by increasing their concentration. The strongest (99.4\%) was recorded by SDS, while the least (79.5) by sodium azide at $10 \mathrm{mM}$. Urea, Triton X-100, imidazole, kojic acid, PMSF, and $\mathrm{H}_{2} \mathrm{O}_{2}$ caused stimulation of the NYSO laccase activity by 1.57, 1.40, 1.407, 1.253, 1.062, and 1.08 times, while higher concentration $(10 \mathrm{mM})$ of kojic acid, PMSF, and $\mathrm{H}_{2} \mathrm{O}_{2}$ caused inhibition in enzyme activity, respectively. 

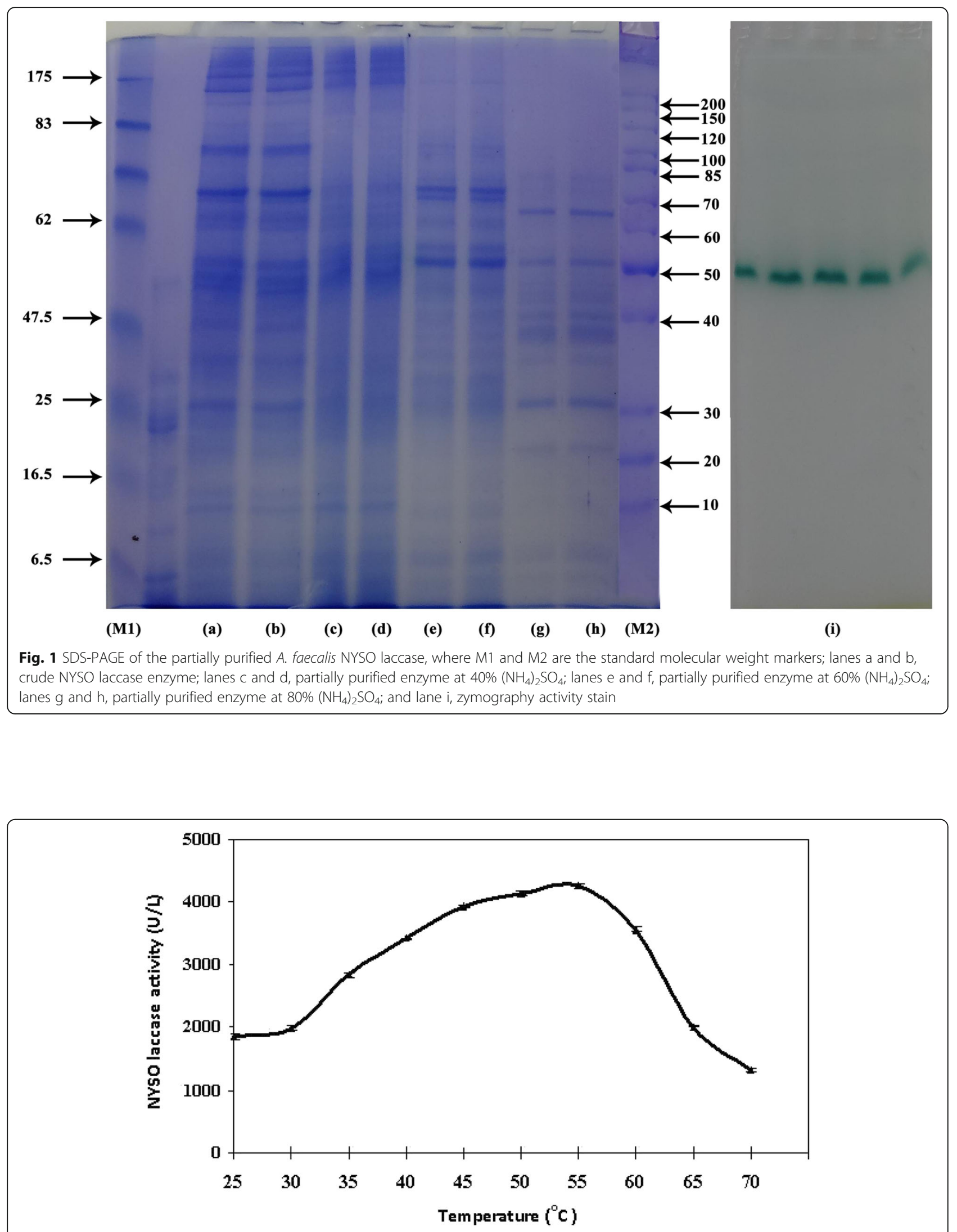

Fig. 2 Optimum temperature for the partially purified A. faecalis NYSO laccase 


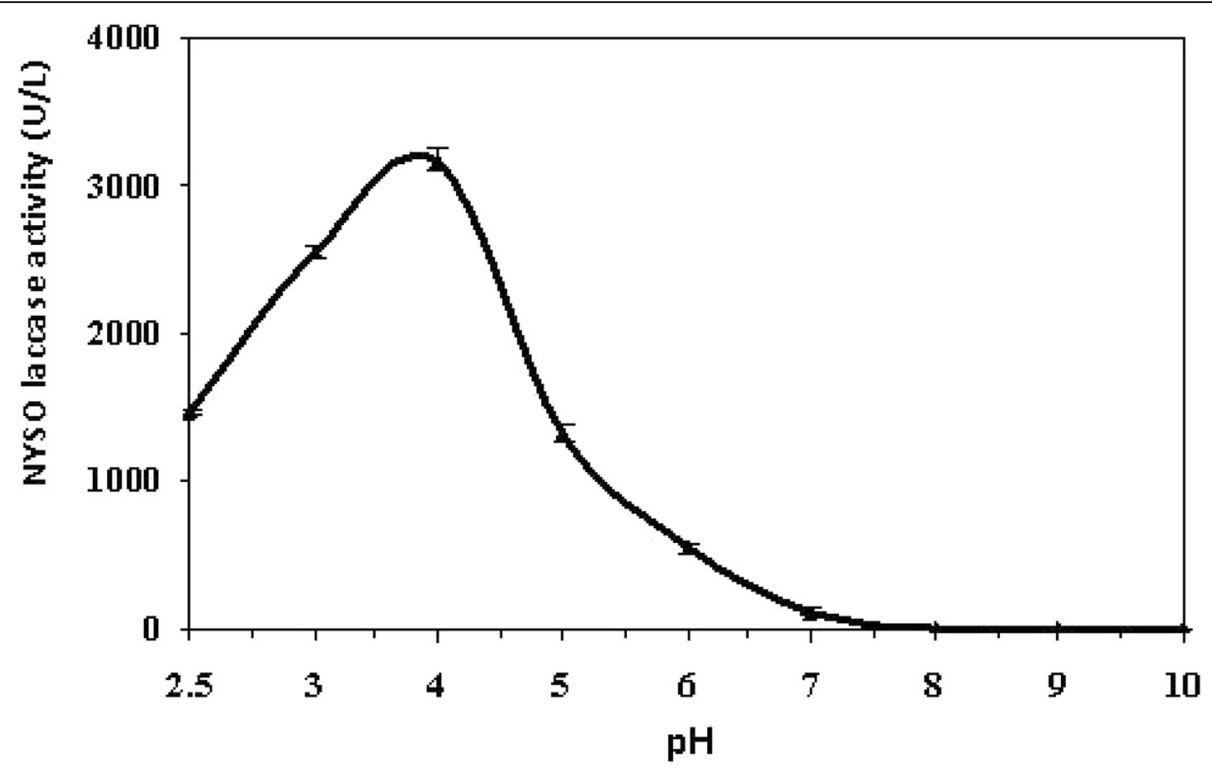

Fig. 3 Optimum pH for the partially purified A. faecalis NYSO laccase

\section{Decolorization of dyes}

Decolorization of dye by partially purified NYSO laccase was evaluated and shown in Table 3 . The results indicate that the tested enzyme exhibited higher potential for decolorization of congo red, methylene blue, and fast green than crystal violet, malachite green, and eriochrome black. Likewise, the rate of decolorization reached $\sim 30$ and $\sim 20 \%$ decrease in absorbance per hour for basic fuchsin and bromophenol blue, respectively. The resistance of Coomassie Brilliant Blue R-250 and bromocresol purple to decolorization by NYSO laccase was noticed.

\section{Substrate specificity}

The results explained that the partially purified laccase showed broad substrate specificity, since all tested substrates were oxidized at different rates. The enzyme exhibited the highest activity with p-anisidine, while it showed a limited specificity towards syringaldazine. As reported in Table 4, the enzyme has the ability to oxidize tannic acid, vanillic acid, and pyrogallol and it showed a high affinity towards the ortho-substituted catechol among the tested substituted phenols. Lastly, the catalytic efficiency of the currently tested laccase towards phenolic substrates could be ordered as follows: p-

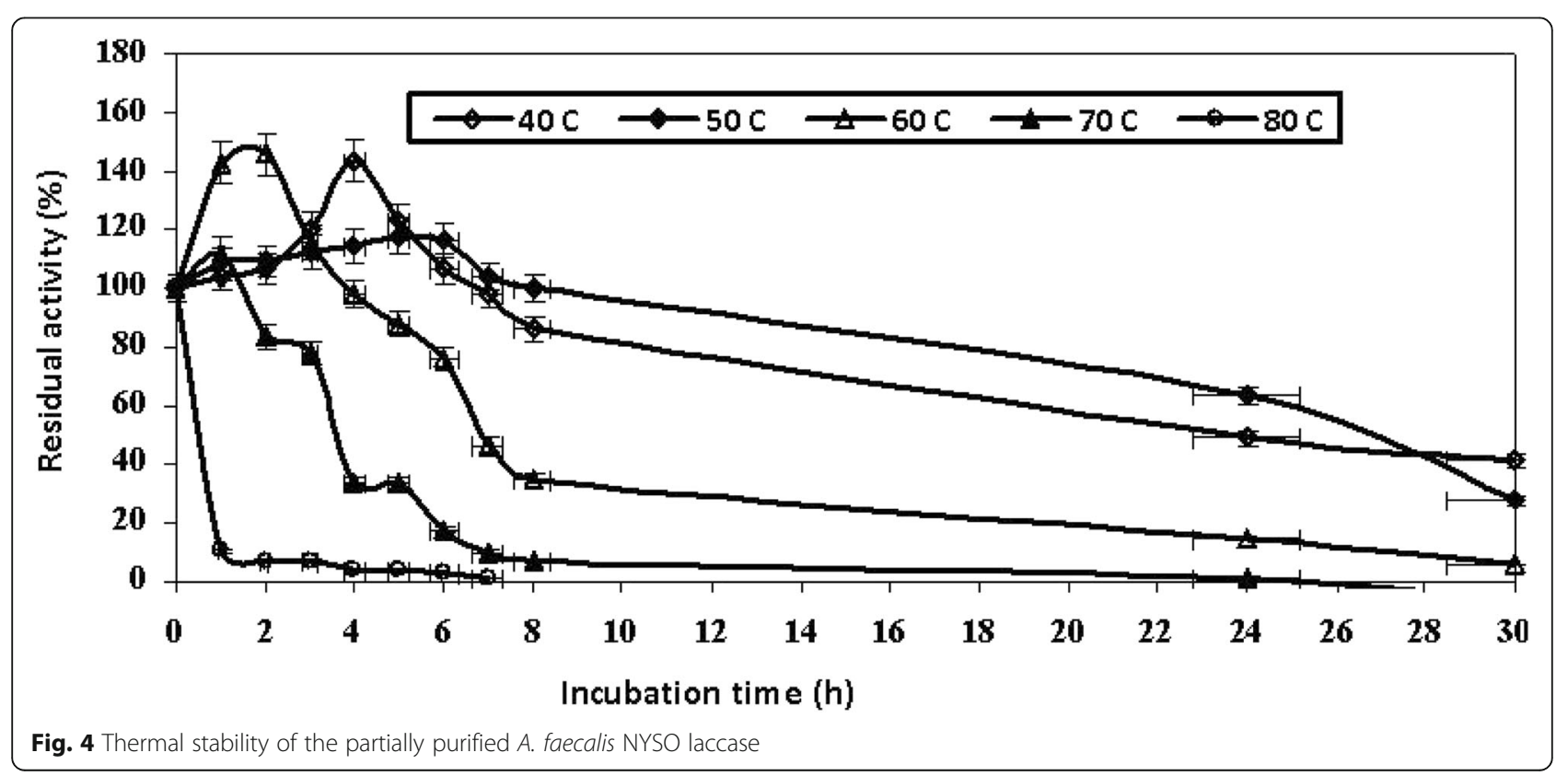




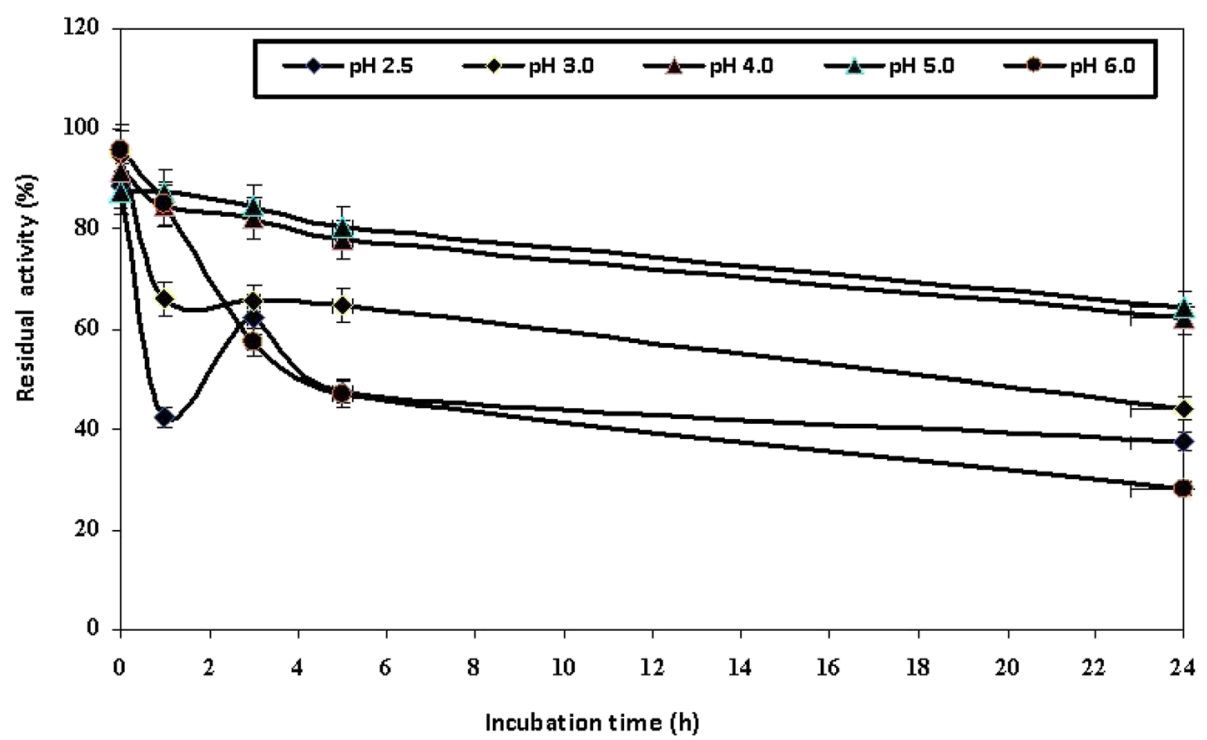

Fig. 5 pH stability of the partially purified A. faecalis NYSO laccase

anisidine > vanillic acid > p-phenylenediamine > 4aminophenol $>$ 4-nitrophenol $>$ tannic acid $>$ hydroquinone $>$ ABTS $>$ catechol $>$ guaiacol $>$ pyrogallol $>$ syringaldazine

\section{Discussion}

Laccases have been mostly isolated and characterized from plants and fungi, and only fungal laccases are currently used in biotechnological applications [19]. Unfortunately, these enzymes usually work efficiently only under mild acidic conditions ( $\mathrm{pH} 4-6)$, whereas the temperature range $\left(30-55^{\circ} \mathrm{C}\right)$ for catalytic activity is suboptimal. In contrast, little is known about bacterial laccases, which have a broad range of substrate specificity useful for industrial applications [19]. As a result, this study listens carefully to the partial purification and biochemical characterization of $A$. faecalis strain NYSO laccase. Initially, such bacterial species is first discovered in feces and able to degrade urea, creating ammonia which increases the $\mathrm{pH}$ of the environment $[20,21]$. Thus, it is categorized as alkali-tolerant but it maintains a neutral $\mathrm{pH}$ in its cytosol to prevent the damaging or denaturing of its charged species and macromolecules [22]. Through the purification procedure for NYSO laccase produced by $A$. faecalis local isolate, it was observed that $40-60 \%$ saturation exhibited the foremost activity. This result is consistent with that attained by Singh et al. [23]. They tested different cuts (0-40, 40-60, and 60-80\%) of ammonium sulfate saturation for partial purification of laccase from alkali-tolerant $\gamma$-proteobacterium JB, where 40-60\% saturation showed the maximum laccase activity (> 60\%). Moreover, activity

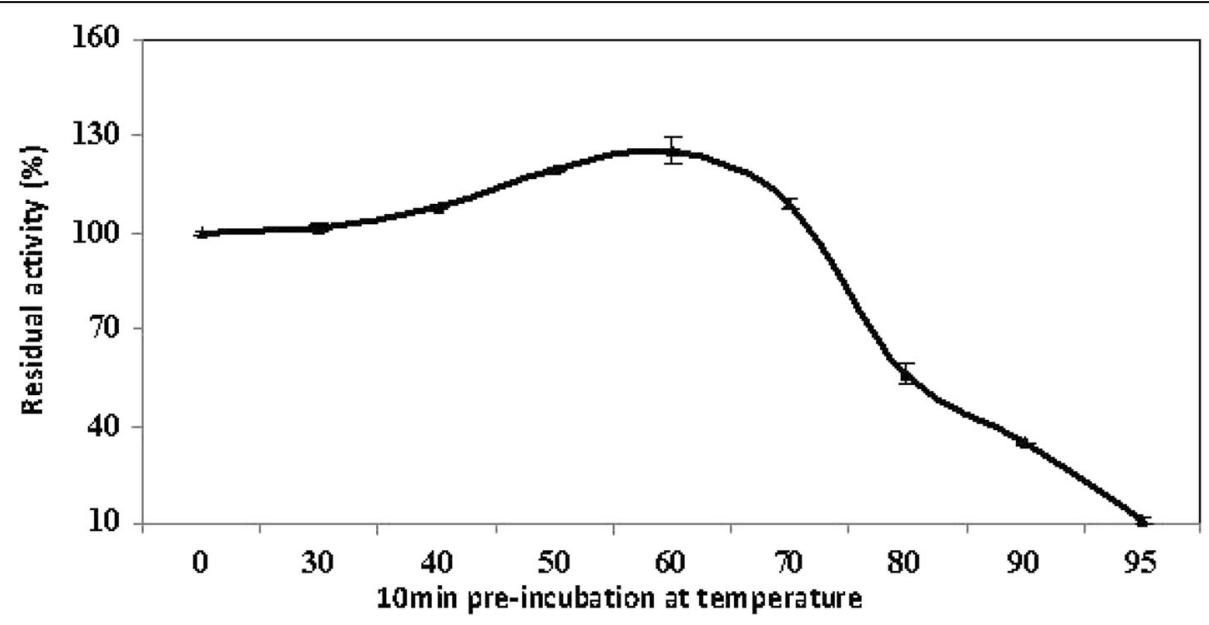

Fig. 6 Thermal inactivation of the partially purified A. faecalis NYSO laccase 


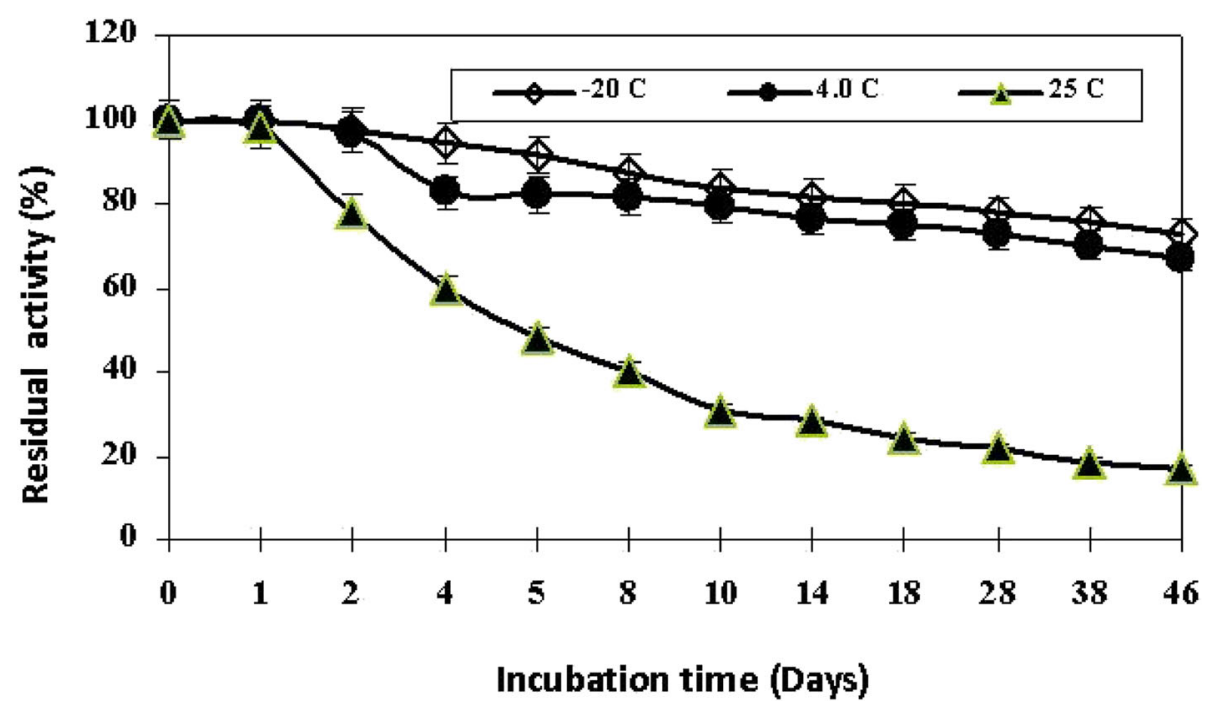

Fig. 7 Effect of storage temperatures on the partially purified A. faecalis NYSO laccase

staining of SDS-PAGE gels for NYSO laccase exhibited a single band at proximate molecular mass $\sim 50 \mathrm{kDa}$. It is nearly close to Serratia marcescens (MTCC 4822) laccase $(53 \mathrm{kDa})$ [24], but lower than the molecular mass of laccase recently obtained from $A$. faecalis (LAC1) $(71 \mathrm{kDa})$ [25] and Aquisalibacillus elongates (75 kDa) [26]. Single band on SDS-PAGE concluded that NYSO is a monoglycoprotein, and the appearance of a colored band is due to oxidation of ABTS substrate.

Interestingly, the studied enzyme showed unlikely promising characteristic features; it can work under high acidic conditions [2.5-5; optimal at $\mathrm{pH} 4.0]$ and at relatively high $\mathrm{T}\left[45-60^{\circ} \mathrm{C}\right.$; optimal at $\left.55^{\circ} \mathrm{C}\right]$. Also, it is more stable against thermal denaturation and has high thermal stability and a long half-life when $\mathrm{T}$ is below $70^{\circ} \mathrm{C}(7 \mathrm{~h}$ half-life at $60^{\circ} \mathrm{C}$ ). Most of the reported bacterial laccase showed preference to work optimally at nearly similar $\mathrm{T}$ and $\mathrm{pH}[27-$ 29 ], but no reported bacterial laccase could work under such a highly acidic condition so far. Unlikewise, LAC1 laccase from A. faecalis works optimally at $\mathrm{pH} 8.0$ [25]. Thermal stability for some reported laccases [29, 30] explained that the laccase activity of Bacillus vallismortis was accelerated after pre-incubation at 70 and $80^{\circ} \mathrm{C}$, this finding matching with the present study. Wang et al. [31] noticed that the spore-bound laccase of Bacillus subtilis WD23 exhibited high thermal stability $\left(2.5 \mathrm{~h}\right.$ half-life at $\left.80^{\circ} \mathrm{C}\right)$.

Furthermore, the investigated NYSO laccase exhibited a high $\mathrm{pH}$ stability, especially in acidic condition ( $\mathrm{pH} 4-5$ ) for 24-h incubation. In contrast, the enzyme was unstable at $\mathrm{pH} 6.0$ where about $49.1 \%$ of activity remained after 5.0-h incubation. These results are in agreement with the results obtained by other investigators [27, 31]. The highest storage stability of the studied laccase was found at $20^{\circ} \mathrm{C}$ and $4.0{ }^{\circ} \mathrm{C}$ for a long time (up to 46 days), while at $25^{\circ} \mathrm{C}$, the enzyme activity decreased to half after 8 days of storage. Storage stability obtained in this investigation matched the results obtained by Singh et al. [23] and Bozoglu et al. [27].

Some metals $\left(\mathrm{Mg}^{2+}, \mathrm{Cr}^{2+}, \mathrm{Mn}^{2+}, \mathrm{Cu}^{2+}, \mathrm{Zn}^{2+}, \mathrm{Ni}^{2+}, \mathrm{Cd}^{2+}\right.$, and $\left.\mathrm{Co}^{2+}\right)$, specially $\mathrm{Cu}^{2+}$, caused strong stimulation for the studied enzyme, while $\mathrm{Fe}^{2+}$ and $\mathrm{Hg}^{2+}$ ions caused a reduction in activity. The high extent activation of laccase by $\mathrm{Cu}^{2+}$ might be caused by the filling of type- 2 copperbinding sites with $\mathrm{Cu}^{2+}$ [32]. Furthermore, most reported laccases from different bacterial sources [33,34] are stimulated in the presence of metal cations such as $\mathrm{Ca}^{2+}$, $\mathrm{Mn}^{2+}, \mathrm{Zn}^{2+}, \mathrm{Cu}^{2+}, \mathrm{Ni}^{2+}, \mathrm{Mg}^{2+}$, and $\mathrm{Co}^{2+}$ which is matching with our results, while the inhibitory effect of $\mathrm{Fe}^{2+}$ and $\mathrm{Hg}^{2+}$ on laccase activity was reported by many investigators $[27,33,34]$ which is similar to our results. In contrast, Niladevi et al. [35] found that $\mathrm{Cd}^{2+}, \mathrm{Co}^{2+}$, and $\mathrm{Ni}^{2+}$ metal ions caused a reduction in Streptomyces psammoticus laccase activity while $\mathrm{Fe}^{2+}$ caused activation.

Some tested agents like EDTA, sodium citrate, imidazole, and sodium oxalate caused strong activation for NYSO laccase activity at $1 \mathrm{mM}$, but cysteine- $\mathrm{HCl}$, DTT, $\beta$ mercaptoethanol, sodium azide, thioglycolic acid, and SDS caused strong inhibition even at low concentration. Similarly, Rosconi et al. [36] reported that imidazole works as an activator, while $\beta$-mercaptoethanol caused a reduction of enzyme activity, though there are controversial reports about the inhibition of laccases by chelators [29]. Moreover, some studies stated that L-cysteine, EDTA, $\mathrm{NaN}_{3}$, SDS, DTT, and thioglycolic acid and $\beta$-mercaptoethanol caused inhibition for some bacterial laccase [27, 29, 34], while $\mathrm{Lu}$ et al. reported that SDS caused stimulation for the Streptomyces sp. laccase enzyme [37]. Additionally, the partially purified NYSO laccase showed decolorization 
Table 2 Effect of some metal ions, chelating agents, and some inhibitors/activators on the partially purified NYSO laccase

\begin{tabular}{|c|c|c|}
\hline \multicolumn{3}{|c|}{ Relative activity (\%) (mean \pm SD) } \\
\hline \multirow[t]{2}{*}{ Tested } & \multicolumn{2}{|c|}{ Metal ion concentration } \\
\hline & $1 \mathrm{mM}$ & $10 \mathrm{mM}$ \\
\hline Control & $100 \pm 0$ & $100 \pm 0$ \\
\hline $\mathrm{MgCl}_{2}$ & $157.8 \pm 0.76$ & $127.8 \pm 0.75$ \\
\hline $\mathrm{CrCl}_{2}$ & $169.2 \pm 2.25$ & $148.7 \pm 1.52$ \\
\hline $\mathrm{MnCl}_{2}$ & $140.1 \pm 0.76$ & $151.9 \pm 1.70$ \\
\hline $\mathrm{HgCl}_{2}$ & $60.1 \pm 0.76$ & $59.9 \pm 0.66$ \\
\hline $\mathrm{CuSO}_{4} \cdot 5 \mathrm{H}_{2} \mathrm{O}$ & $171.1 \pm 0.89$ & $241.8 \pm 2.02$ \\
\hline $\mathrm{FeSO}_{4} \cdot 7 . \mathrm{H}_{2} \mathrm{O}$ & $15.6 \pm 0.58$ & $10.9 \pm 0.85$ \\
\hline $\mathrm{NiSO}_{4}$ & $141.2 \pm 1.10$ & $198.5 \pm 1.25$ \\
\hline $\mathrm{CdSO}_{4}$ & $167.9 \pm 1.76$ & $166.5 \pm 1.36$ \\
\hline $\mathrm{ZnSO} 4.7 \mathrm{H}_{2} \mathrm{O}$ & $177.4 \pm 2.16$ & $171.8 \pm 2.01$ \\
\hline \multirow[t]{3}{*}{$\mathrm{CoSO}_{4}$} & $150.6 \pm 0.65$ & $191.3 \pm 1.42$ \\
\hline & \multicolumn{2}{|c|}{ Chelating agent concentration } \\
\hline & $1 \mathrm{mM}$ & $10 \mathrm{mM}$ \\
\hline EDTA & $215.6 \pm 1.25$ & $24.6 \pm 0.53$ \\
\hline Sodium citrate & $114.7 \pm 0.3$ & $99.4 \pm 0.51$ \\
\hline \multirow[t]{3}{*}{ Sodium oxalate } & $103.6 \pm 2.36$ & $95.9 \pm 1.79$ \\
\hline & \multicolumn{2}{|c|}{ Inhibitor/activator concentration } \\
\hline & $1 \mathrm{mM}$ & $10 \mathrm{mM}$ \\
\hline Sodium azide & $69.0 \pm 0.10$ & $20.5 \pm 0.50$ \\
\hline DTT & $7.8 \pm 2.02$ & $5.5 \pm 0.47$ \\
\hline Urea & $157.3 \pm 2.33$ & 127. \pm 1.67 \\
\hline Imidazole & $140.7 \pm 1.04$ & $125.4 \pm 1.58$ \\
\hline Kojic acid & $125.3 \pm 2.0$ & $71.1 \pm 1.27$ \\
\hline Cysteine- $\mathrm{HCl}$ & $9.3 \pm 1.10$ & $2.1 \pm 0.1$ \\
\hline$\beta$-Mercaptoethanol & $7.4 \pm 0.52$ & $4.6 \pm 0.5$ \\
\hline Thioglycolic acid & $11.4 \pm 1.26$ & $9.6 \pm 0.5$ \\
\hline PMSF & $106.2 \pm 1.04$ & $30.1 \pm 0.6$ \\
\hline $\mathrm{H}_{2} \mathrm{O}_{2}$ & $100.8 \pm 2.25$ & $89.5 \pm 0.5$ \\
\hline Triton X-100 & $140.0 \pm 0.95$ & $116.2 \pm 1.31$ \\
\hline SDS & $2.9 \pm 0.1$ & $0.60 \pm 0.045$ \\
\hline
\end{tabular}

activity towards wide varieties of synthetic dyes which is similar to mostly studied bacterial laccases [28, 29, 31].

On substrate specificity, the enzyme exhibited the highest activity towards p-anisidine; on the other hand, it showed a limited specificity towards syringaldazine (a dimer of two molecules of 2, 6 dimethoxyphenol linked by an azide bridge); these findings were in congruence with the result obtained by Niladevi et al. [35]. However, syringaldazine was used as the oxidation substrate by
Table 3 Decolorization potential of partially purified NYSO laccase

\begin{tabular}{|c|c|c|c|}
\hline Tested dye & $\begin{array}{l}\lambda_{\max } \\
(\mathrm{nm})\end{array}$ & $\begin{array}{c}\text { Decolorization } \\
\text { rate }^{a}(\%) \\
\text { (mean } \pm \text { SD) }\end{array}$ & $\begin{array}{l}\text { Average decolorization } \\
\text { rate }^{\mathrm{a}}(\mathrm{mg} / \mathrm{h}) \\
(\text { mean } \pm \text { SD) }\end{array}$ \\
\hline Congo red & 497 & $61.3 \pm 2.7$ & $122.26 \pm 5.3$ \\
\hline Crystal violet & 590 & $47.16 \pm 1.35$ & $94.07 \pm 2.69$ \\
\hline Methylene blue & 665 & $55.56 \pm 0.63$ & $110.82 \pm 1.26$ \\
\hline Fast green & 625 & $54.3 \pm 1.52$ & $108.36 \pm 3.04$ \\
\hline Basic fuchsin & 544 & $32.0 \pm 3.0$ & $63.82 \pm 6.98$ \\
\hline Bromophenol blue & 592 & $21.3 \pm 2.08$ & $42.54 \pm 4.15$ \\
\hline Malachite green & 616 & $36.56 \pm 6.50$ & $72.93 \pm 12.9$ \\
\hline Bromocresol purple & 419 & $18.6 \pm 3.21$ & $37.22 \pm 6.41$ \\
\hline Eriochrome black $T$ & 503 & $36.0 \pm 1.0$ & $71.80 \pm 1.99$ \\
\hline $\begin{array}{l}\text { Coomassie Brilliant } \\
\text { Blue R-250 }\end{array}$ & 465 & $12.53 \pm 2.50$ & $24.99 \pm 4.98$ \\
\hline
\end{tabular}

other investigators [31, 38]. Niladevi et al. [35] reported that the pyrogallol was denoted as the most suitable substrate for laccase from Streptomyces psammoticus while vanillic acid was not efficiently oxidized; these are dissimilar to our findings. According to the current results, lower activity was noted towards guaiacol, due to laccase inactivation by reaction products [39]. However, NYSO laccase positively interacts with guaiacol in the screening experiment. Similarly, Sheikhi et al. state that guaiacol is more suitable for screening laccase producer, but it is not efficient for assaying laccase [13].

Table 4 Substrate specificity of the partially purified NYSO laccase

\begin{tabular}{|c|c|c|c|c|}
\hline \multirow[t]{2}{*}{ Substrates } & \multirow{2}{*}{$\begin{array}{l}\lambda_{\max } \\
(\mathrm{nm})\end{array}$} & \multirow{2}{*}{$\begin{array}{l}\text { Extinction } \\
\text { coefficient } \\
\varepsilon\left(\mathrm{mM}^{-1}\right. \\
\left.\mathrm{cm}^{-1}\right)\end{array}$} & \multicolumn{2}{|c|}{ Activity $^{\mathrm{a}}$ (U/L) (mean \pm SD) } \\
\hline & & & $1 \mathrm{mM}$ & $20 \mathrm{mM}$ \\
\hline ABTS & 436 & 29.3 & $1300 \pm 9.02$ & $7271 \pm 6.98$ \\
\hline Catechol & 450 & 26 & $922 \pm 8.49$ & $4378 \pm 5.77$ \\
\hline Pyrogallol & 450 & 35 & $785 \pm 4.11$ & $3336 \pm 4.97$ \\
\hline p-anisidine & 350 & 1.173 & $26546 \pm 108.7$ & $83847 \pm 50.57$ \\
\hline 4-nitrophenol & 405 & 18.1 & $4270 \pm 8.16$ & $7920 \pm 8.16$ \\
\hline Hydroquinone & 525 & 17.542 & $1318 \pm 4.05$ & $2585 \pm 8.61$ \\
\hline 4-aminophenol & 470 & 3.4 & $7074 \pm 8.99$ & $26390 \pm 69.76$ \\
\hline p.phylenediamine & 525 & 14.68 & $11512 \pm 15.14$ & $19250 \pm 122.5$ \\
\hline Syringaldazine & 530 & 65 & $744 \pm 11.43$ & $2179 \pm 3.09$ \\
\hline Guaiacol & 465 & 26.6 & $801 \pm 7.25$ & $2446 \pm 11.05$ \\
\hline Tannic acid & 458 & 27.200 & $1415 \pm 14.72$ & $3340 \pm 4.9$ \\
\hline Vanillic acid & 390 & 2.340 & $14606 \pm 76.54$ & $26786 \pm 84.01$ \\
\hline
\end{tabular}

${ }^{2}$ Values represent mean \pm SD 


\section{Conclusion}

Laccases are one of the most widely used enzymes in industry. Thus, this study has focused on addressing the major characteristic properties of newly partially purified YNSO laccase produced by alkali-tolerant Egyptian isolate (A. faecalis NYSO). The theme chosen for this study and noted promising characteristics of the studied enzyme opens the door for many applications. The promising unusual features can be summarized in the following points: it is able to work in a highly acidic condition up to $\mathrm{pH} 2.5$ and has high stability against thermal denaturation up to $70{ }^{\circ} \mathrm{C}$ for $1 \mathrm{~h}$ and high stability at $\mathrm{pH}$ range $4.0-5.0$. The enzyme showed the highest storage stability at $-20^{\circ} \mathrm{C}$ and $4.0^{\circ} \mathrm{C}$ up to 46 days, while at $25^{\circ} \mathrm{C}$ the enzyme activity decreased to more than half after 8 days' storage time. Some metals $\left(\mathrm{Mg}^{+2}, \mathrm{Cr}^{+2}, \mathrm{Mn}^{+2}, \mathrm{Cu}^{+2}, \mathrm{Zn}^{+2}, \mathrm{Ni}^{+2}, \mathrm{Cd}^{+2}\right.$, and $\mathrm{Co}^{+2}$ ) caused strong stimulation for the studied NYSO enzyme, while $\mathrm{Fe}^{+2}$ and $\mathrm{Hg}^{+2}$ ions caused a reduction of the activity. Also, chelating agents (EDTA, sodium citrate, and sodium oxalate) caused strong activation for enzyme activity at $1 \mathrm{mM}$. Cysteine-HCl, DTT, $\beta$-mercaptoethanol, sodium azide, thioglycolic acid, and SDS caused strong inhibition for NYSO laccase even at low concentrations. Additionally, the partially purified studied enzyme showed decolorization activity towards wide variants of synthetic dyes. The enzyme exhibited the highest activity with panisidine, and its catalytic efficiency of phenolic substrates could be ordered as follows: $\mathrm{p}$-anisidine $>$ vanillic acid $>\mathrm{p}$ phenylenediamine $>$ 4-aminophenol $>$ 4-nitrophenol > tannic acid $>$ hydroquinone $>$ ABTS $>$ catechol $>$ guaiacol $>$ pyrogallol $>$ syringaldazine. The aforementioned promising features of NYSO laccase make it suitable for various industrial processes, decolorization of industrial effluent, and wastewater treatment.

\section{Abbreviations \\ A.: Alcaligenes; EDTA: Ethylenediamine tetraacetic acid; DTT: Dithiothreitol: SDS-PAGE: Sodium dodecyl sulfate-polyacrylamide gel electrophoresis; PMSF: Phenylmethylsulfonyl fluoride; PAHs: Polycyclic aromatic hydrocarbons; ABTS: 2,2'-Azino-bis(3-ethylbenzothiazoline-6-sulfonic acid); BSA: Bovine serum albumin; T: Temperature}

\section{Acknowledgements}

The authors are extremely grateful to the City of Scientific Research and Technological Applications (SRTA-City), Alexandria, Egypt, for providing all facilities to complete this work. The authors would like also to acknowledge Prof. Dr. Yasser R. Abdel-Fattah for advice and critical comments to improve this work.

\section{Authors' contributions}

SAA performed the experimental part of the work and wrote the main manuscript text. AMA prepared the figures of the work. RMR performed the analysis part. NAS designed the experiments and revised the manuscript. The authors read and approved the final manuscript.

\section{Funding}

This research received no specific grant from any funding agency in the public, commercial, or not-for-profit sectors.

\section{Availability of data and materials}

All data generated or analyzed during this study are included in this published article.

Ethics approval and consent to participate

This article does not contain any studies involving animals or human participants performed by any of the authors.

Consent for publication

Not applicable

\section{Competing interests}

The authors declare that they have no competing interests.

\section{Author details}

${ }^{1}$ Bioprocess Development Department, Genetic Engineering and Biotechnology Research Institure (GEBRI), City of Scientific Research and Technological Applications (SRTA-City), New Burg El-Arab City, Alexandria 21934, Egypt. ${ }^{2}$ Environmental Studies Department, Institute of Graduate Studies and Research, Alexandria, Egypt.

Received: 4 May 2020 Accepted: 27 October 2020

Published online: 27 November 2020

\section{References}

1. Sutherland TD, Horne I, Weir KM, Coppin CW, Williams MR, Selleck M, Oakeshott JG (2004) Enzymatic bioremediation: from enzyme discovery to applications. Clin Exp Pharmacol Physiol 31:817-821

2. Riva S (2006) Laccases: blue enzymes for green chemistry. Trends Biotechnol 24:219-226

3. Pieper DH, dos Santos VAM, Golyshin PN (2004) Genomic and mechanistic insights into the biodegradation of organic pollutants. Curr Opin Biotechnol 15:215-224

4. Ahuja SK, Ferreira GM, Moreira AR (2004) Utilization of enzymes for environmental applications. Crit Rev Biotechnol 24:125-154

5. Moreno AD, Ibarra D, Eugenio ME, Tomás Pejó E (2020) Laccases as versatile enzymes: from industrial uses to novel applications. J Chem Technol Biotechnol 95:481-494. https://doi.org/10.1002/jctb.6224

6. Galhaup C, Goller S, Peterbauer CK, Strauss J, Haltrich D (2002) Characterization of the major laccase isoenzyme from Trametes pubescens and regulation of its synthesis by metal ions. Microbiology 148:2159-2169.6

7. Thurston CF (1994) The structure and function of fungal laccases. Microbiology 140:19-26

8. Schmid RD, Urlacher VB (2007) Catalytic applications of laccase. In: Modern biooxidation: enzymes, reactions and application. Wiley-VCH, Weinheim, pp 43-75

9. Janusz G, Pawlik A, Swiderska-Burek U, Polak J, Sulej J, Jarosz-Wilkołazka A, Paszczyński A (2020) Laccase properties, physiological functions, and evolution. Int J Mol Sci 21:966. https://doi.org/10.3390/ijms21030966

10. Seyedi ZS, Zahraei Z, Kashi FJ (2020) Decolorization of reactive black 5 and reactive red 152 Azo dyes by new haloalkaliphilic bacteria isolated from the textile wastewater. Curr Microb 77:2084-2092

11. Desai SS, Nityanand C (2011) Microbial laccase and their applications: a review. Asian J Biotechnol 3(2):98-124.1

12. Abdelgalil SA, Morsi AA, Reyed RM, Soliman NA (2018) Application of experimental designs for optimization the production of Alcaligenes faecalis NYSO laccase. J Sci Ind Res 77(12):713-722

13. Sheikhi F, Ardakani MR, Enayatizamir N, Rodriguez-Couto S (2012) The determination of assay for laccase of Bacillus subtilis WPI with two classes of chemical compounds as substrates. Indian J Microbiol 52(4):701-707

14. Niku-Paavola ML, Raaska L, Itävaara M (1990) Detection of white-rot fungi by a non-toxic stain. Mycol Res 94(1):27-31

15. Lowry OH, Rosebrough NJ, Farr AL, Randall RJ (1951) Protein measurement with the Folin phenol reagent. J Biol Chem 193(1):265-275

16. Altman DG, Bland JM (2005) Standard deviations and standard errors. BMJ 331(7521):903

17. Laemmli UK (1970) Cleavage of structural proteins during the assembly of the head of bacteriophage T4. Nature 227:680-685

18. Shah MP, Patel KA, Nair SS, Darji AM (2013) Microbial degradation and decolorization of reactive orange dye by strain of Pseudomonas spp. Int J Environ Biorem Biodeg 1(1):1-5 
19. Chandra R, Chowdhary P (2015) Properties of bacterial laccases and their application in bioremediation of industrial wastes. Environ Sci Process Impacts. https://doi.org/10.1039/c4em00627e

20. Sarkar JK, Choudhury B, Tribedi BP (1959) Alcaligenes faecalis; its systematic study. Indian J Med Res 47:1-12

21. Phung LT, Trimble WL, Meyer F, Gilbert JA, Silver S (2012) Draft genome sequence of Alcaligenes faecalis subsp. faecalis NCIB 8687 (CCUG 2071). J Bacteriol 194:5153

22. Castellani A, Chalmers AJ (1919) Manual of tropical medicine. William Wood and Company, New York, pp 934-936

23. Singh G, Capalash N, Goel R, Sharma PA (2007) pH-stable laccase from alkali-tolerant $\gamma$-proteobacterium JB: purification, characterization and indigo carmine degradation. Enzym Microb Technol 41(6):794-799

24. Kaira GS, Dhakar K, Pandey AA (2015) Psychrotolerant strain of Serratia marcescens (MTCC 4822) produces laccase at wide temperature and pH range. AMB Express 5(1):1-8

25. Mehandia S, Sharma SC, Arya SK (2020) Isolation and characterization of an alkali and thermostable laccase from a novel Alcaligenes faecalis and its application in decolorization of synthetic dyes. Biotechnol Rep 25:e00413

26. Rezaei S, Shahverdi AR, Faramarzi MA (2017) Isolation, one-step affinity purification, and characterization of a polyextremotolerant laccase from the halophilic bacterium Aquisalibacillus elongatus and its application in the delignification of sugar beet pulp. Bioresour Technol 230:67-75

27. Bozoglu C, Adiguzel A, Nadaroglu H, Yanmis D, Gulluce M (2013) Purification, characterization of laccase from newly isolated thermophilic Brevibacillus sp.(Z1) and its applications in removal of textile dyes. Res J Biotechnol 8(9):56-66

28. Shah MP (2015) Microbial decolorization of dyes by laccase. Int J Curr Microbiol App Sci 4:1-14

29. Lončar N, Gligorijević N, Božić N, Vujčić Z (2014) Congo red degrading laccases from Bacillus amyloliquefaciens strains isolated from salt spring in Serbia. Int. Biodeterior Biodegrad 91:18-23

30. Zhang C, Diao H, Lu F, Bie X, Wang Y, Lu Z (2012) Degradation of triphenylmethane dyes using a temperature and $\mathrm{pH}$ stable spore laccase from a novel strain of Bacillus vallismortis. Bioresour Technol 126:80-86

31. Wang C, Zhao M, Lu L, Wei X, Li T (2011) Characterization of spore laccase from Bacillus subtilis WD23 and its use in dye decolorization. Afr J Biotechnol 10(11):2186-2192

32. Shekher R, Sehgal S, Kamthania M, Kumar A (2011) Laccase: microbial sources, production, purification, and potential biotechnological applications. Enzyme Res 217861:1-11

33. Fernandes TAR, da Silveira WB, Passos FML, Zucchi TD (2014) Characterization of a thermotolerant laccase produced by Streptomyces sp. SB086. Ann Microbiol 64(3):1363-1369

34. Sondhi S, Sharma P, Saini S, Puri N, Gupta N (2014) Purification and characterization of an extracellular, thermo-alkali-stable, metal tolerant laccase from Bacillus tequilensis SN4. PLoS One 9(5):1-10

35. Niladevi KN, Jacob N, Prema P (2008) Evidence for a halotolerant-alkaline laccase in Streptomyces psammoticus: purification and characterization. Process Biochem 43(6):654-660

36. Rosconi F, Fraguas LF, Martínez-Drets G, Castro-Sowinski S (2005) Purification and characterization of a periplasmic laccase produced by Sinorhizobium meliloti. Enzym Microb Technol 36(5):800-807

37. Lu L, Zeng G, Fan C, Ren X, Wang C, Zhao Q, Jiang M (2013) Characterization of a laccase-like multicopper oxidase from newly isolated Streptomyces sp. C1 in agricultural waste compost and enzymatic decolorization of azo dyes. Biochem Eng J 72:70-76

38. Held C, Kandelbauer A, Schroeder M, Cavaco-Paulo A, Gübitz GM (2005) Biotransformation of phenolics with laccase containing bacterial spores. Environ Chem Lett 3(2):74-77

39. Robles A, Lucas R, de Cienfuegos GA, Gálvez A (2000) Phenol-oxidase (laccase) activity in strains of the hyphomycete Chalara paradoxa isolated from olive mill wastewater disposal ponds. Enzym Microb Technol 26(7):484-490

\section{Publisher's Note}

Springer Nature remains neutral with regard to jurisdictional claims in published maps and institutional affiliations.

\section{Submit your manuscript to a SpringerOpen ${ }^{\circ}$ journal and benefit from:}

- Convenient online submission

- Rigorous peer review

- Open access: articles freely available online

- High visibility within the field

- Retaining the copyright to your article

Submit your next manuscript at $\boldsymbol{\nabla}$ springeropen.com 